\title{
'Removal of Some Heavy Metals from Electrical Power Plant Effluents Discharged Into Aquatic Ecosystem using Low Cost Adsorbents M.I.Aly , H.M.H.Gad ${ }^{1}$, M.H.Abdo' ${ }^{2}$, M.H.M.Radwan ${ }^{3}$ and M.Mahmoud ${ }^{3}$ \\ ${ }^{1}$ Hot Laboratories and Waste Management Center, Egyptian Atomic Energy Authority, P.O.Box 13759, Ain- Shams, Cairo, Egypt \\ ${ }^{2}$ National Institute of Oceanography and Fisheries, Egypt \\ ${ }^{3}$ Chemistry Dept., Faculty of Science, Benha Univ., Benha, Egypt \\ E-Mail: Mohamed.ibrahim@eaea.org.eg
}

\begin{abstract}
The preparation of nano-pore size activated carbon from different biomass (rice husk: RH and sawdust: SD) was investigated as a suitable adsorbent for the removal of some heavy metal ions such as $\mathrm{Pb}$ (II), $\mathrm{Zn}$ (II), Fe (II), Cd (II) and $\mathrm{Cu}$ (II) from Surface water stream through batch adsorption process. The prepared activated carbon (AC) was characterized by Fourier transform infrared spectroscopy (FTIR) and surface area analyzer. The effects of initial metal concentration, contact time, $\mathrm{pH}$ and adsorbent dose on the sorption of metal ions were studied. It was found that the sorption capacities of the AC decreased in the order: $\mathrm{Pb}$ (II), $\mathrm{Zn}$ (II), Fe (II), Cd (II) and $\mathrm{Cu}(\mathrm{II})$.
\end{abstract}

Keywords: Aquatic ecosystem; Removal; Heavy metal ions; Wastewater; Low Cost Adsorbents.

\section{Introduction}

Water pollution due to organic contaminants is a serious issue because of acute toxicities and carcinogenic nature of the pollutants. Among various water treatment methods, adsorption is supposed as the best one due to its inexpensiveness, universal nature and ease of operation. Many waste materials used include fruit wastes, coconut shell, scrap tiers, bark and other tannin-rich materials, sawdust and other wood type materials, rice husk, petroleum wastes, fertilizer wastes, fly ash, sugar industry wastes blast furnace slag, chitosan and sea food processing wastes, seaweed and algae, peat moss, clays, red mud, zeolites, sediment and soil, ore minerals etc. The sediment adsorbents have been found to remove various organic pollutants ranging from 80 to $99.9 \%[1]$. Thermal pollution is the degradation of water quality by any process that changes ambient water temperature. A common cause of thermal pollution is the use o water as a coolant by power plant and industrial manufactures. When water used as a coolant is returned to natural environment at a higher temp. Decreases. Oxygen supply and affects ecosystem composition [2].

Different contaminants are released to water with the rapid industrialization of human society, including heavy metal ions, organics, bacteria, viruses, and so on, which are serious harmful to human health. Among all water contaminations, heavy metal ions have high toxic and nonbiodegradable properties; can cause severe health problems in animals and human beings [1, 2].The disposal of heavy metals is a consequence of several activities like chemical manufacturing, painting and coating, mining, extractive metallurgy, nuclear and other industries [1,2]. Therefore, the treatment and removal of heavy metal ions received considerable attention [3, 4]. A number of techniques have been developed for treating water and wastewaters embedded with heavy metals. It includes chemical precipitation, reverse osmosis, membrane filtration, solvent extraction, ion exchange and adsorption [48]. Adsorption is found to be more appropriate and user friendly technique as it has a lower cost of design and operation and it is simple to apply. The use of nano-adsorbent materials offers significant improvement with their extremely high specific surface area, fast dissolution, high reactivity and associated sorption sites, short intra-particle diffusion distance and tunable pore size and surface chemistry [5].

\section{Materials and methods}

\subsection{Preparation and characterization of activated carbon}

Nano-pore size activated carbon from different biomass (rice husk: RH and sawdust: SD), were supplied from El-Dakahlyia Governorate in Egypt [9]. They were collected, washed with distilled water, dried at $110{ }^{\circ} \mathrm{C}$ for $48 \mathrm{hrs}$, to facilitate subsequent crushing. The dried $\mathrm{RH}$ and SD were crushed and used for preparation of activated carbon by impregnation in phosphoric acid. The concentration of $70 \%(\mathrm{w} / \mathrm{v}) \mathrm{H}_{3} \mathrm{PO}_{4}(\mathrm{BDH})$ was obtained by dilution of 85 wt. \%. Two equal weights of the crushed agroresidues were prepared; The two samples were impregnated in sufficient $\mathrm{H}_{3} \mathrm{PO}_{4}$ solution, mixed and heated to $80{ }^{\circ} \mathrm{C}$ for 1.5 hour and then left overnight. The treated masses were dried at $80^{\circ} \mathrm{C}$ overnight, admitted into the carbonization tube, then wellplaced in electric furnace. The temperature was increased with the rate of $5{ }^{\circ} \mathrm{C} / 1 \mathrm{~min}$ to attain $350{ }^{\circ} \mathrm{C}$ which allowed free evolution of volatiles and draining of tarry matter. After that, pure steam is introduced from the top of the tube using a steam generator to hold the internal temperature at $500{ }^{\circ} \mathrm{C}$ for 1.5 hours. The obtained materials (activated carbon and $b$ from $\mathrm{RH}$ and SD respectively) were washed with hot distilled water. The final products 
'Removal of Some Heavy Metals from Electrical Power Plant Effluents

were desiccated at $110{ }^{\circ} \mathrm{C}$ for 48 hours, and finally kept in tightly closed bottles.

\subsection{Sampling stations}

Seven stations were selected at the area affected by thermal pollution produced from electric power plants at Embaba and Shoubra El- Keima electric power stations.

\subsection{Water samples and analysis}

Subsurface water samples (at depth $60 \mathrm{~cm}$ ) were collected from seven cross sections at the main channel and two banks of the branch by using poly vinyl Van Dorn plastic bottle (2L).Heavy metals water samples were collected at selected stations and preserved by adding $5 \mathrm{ml}$ of conc. HNO3 to one liter of water sample. The digestion of water sample by adding $10 \mathrm{ml}$ of conc. HNO3 and evaporate to reach $50 \mathrm{ml}$. Iron, copper zinc, cadmium and lead were measured by using ICP-OES, Model (LEEMAN LABS-Profile plus), USA ( $\pm 0.1 \mathrm{ppb}$-up to $10 \mathrm{ppm})$.

\subsection{Batch adsorption studies}

To study the effect of contact time, $\mathrm{pH}$ of solution, type of adsorbent and adsorbate; the sorption experiments of heavy metal on synthetic nano adsorbents were carried out at constant temperature $\left(25 \pm 1{ }^{\circ} \mathrm{C}\right)$ using $50 \mathrm{~mL}$ polypropylene tube with screw cap. The solutions $\mathrm{pH}$ was adjusted by additions of $\mathrm{HNO}_{3}$ or $\mathrm{NaOH}$ and the $\mathrm{pH}$ values at the beginning and the end of experiments were measured using a digital $\mathrm{pH}$ meter of Hanna Instruments type at the ambient laboratory temperature degree $25 \pm 1{ }^{\circ} \mathrm{C}$ with a $\mathrm{BNC}$ water proof electrode. All tests were conducted using $0.05 \mathrm{gm}$ of adsorbent with $10 \mathrm{ml}$ solutions containing the metal ions of initial concentration $50 \mathrm{mg} / \mathrm{l}$ for various time ranged from5 to 120 minutes. In all cases, the sorbent were removed from the solutions by centrifugation for 20 minutes $4000 \mathrm{rpm}$ using Hettich Centrifuge, model ROTOFX32A. Atomic Absorption Spectrometer (AAS), Model (S4) thermo Electron Corporation was used for the measurement of the metal ions concentration in the aqueous phase. For batch investigation, a good shaking for the two phases was achieved using a thermostatic mechanical shaker of the type Julabo SW-20C, Germany. The amount of metal adsorbed was calculated by the simple mass balance relationship:

$$
q_{e}=\left(C_{o}-C_{e}\right) \times \frac{V}{W}
$$

Where Co and Ce are initial and final concentration, $\mathrm{V}$ is the volume of solution per liter and $\mathrm{W}$ is the weight of adsorbent in $\mathrm{g}$ and the \% removal of each metal was calculated from the following equation:

$\%$ removal $=\frac{\left(\mathrm{C}_{\mathrm{o}}-\mathrm{C}_{\mathrm{e}}\right)}{\mathrm{C}_{\mathrm{O}}} \times 100$

\subsubsection{Effect of $\mathrm{pH}$}

The $\mathrm{pH}$ of metal solutions has been identified as the most "important variable governing sorption. This is partly due to the fact that the distribution of metal chemical species in solution varies with the $\mathrm{pH}$ and partly that this parameter influences on the net charge of the sorbent. The effect of $\mathrm{pH}$ on the species sorption was studied by adjusting the initial solution $\mathrm{pH}$ within the range $1.0-8.0$ using $0.1 \mathrm{MHCl}$ and $0.1 \mathrm{M} \mathrm{NaOH}$. In these experiments, metal initial concentration was around $50 \mathrm{mg} / \mathrm{L}$.

\subsubsection{Sorption study}

For the adsorption isotherm experiments, the initial metal concentration was varied within the range $0-50 \mathrm{mg} / \mathrm{L}$; temperature was $25 \pm 1{ }^{\circ} \mathrm{C}$, and $\mathrm{pH}=8$, this $\mathrm{pH}$ was selected based on batch tests conducted to determine the effect of $\mathrm{pH}$ on the sorbent capacities.

\section{Results and discussion characterization of prepared activated carbon a- Surface area}

The surface area analysis of the two prepared activated carbon from rice husk and sawdust and the pore size distribution are summarized in the following Table (1) and Fig $(1,2)$.

\subsection{Effect of pH}

The effect of $\mathrm{pH}$, while keeping all other experimental conditions fixed as mentioned in the experimental section, was investigated in the range (1-8). It was found that the adsorption of $\mathrm{Fe}$ (II), $\mathrm{Cu}$ (II), $\mathrm{Zn}$ (II), $\mathrm{Pb}$ (II) and $\mathrm{Cd}$ (II) increases by increasing $\mathrm{pH}$ from 1 to 8 in case of using A.C (A) as adsorbent, whereas in case of using A.C.(B) as adsorbent the adsorption of $\mathrm{Fe}$ (II), $\mathrm{Cu}$ (II), Zn (II), $\mathrm{Pb}$ (II) and $\mathrm{Cd}$ (II) increases by increasing the $\mathrm{pH}$ within the investigated range. Results of the Fe (II), $\mathrm{Cu}$ (II), $\mathrm{Zn}$ (II), $\mathrm{Pb}$ (II) and $\mathrm{Cd}$ (II) sorption as a function of initial $\mathrm{pH}$ are presented in Fig.(3) and Fig (4) For Activated carbon (A) and (B), respectively.

Table (1) The surface area analysis of the two prepared activated carbon.

\begin{tabular}{lcc}
\hline Parameters & RH activated carbon & SD activated carbon \\
\hline Surface Area & $261.593 \mathrm{~m}^{2} / \mathrm{g}$ & $1033.588 \mathrm{~m}^{2} / \mathrm{g}$ \\
Total pore volume & $0.2372 \mathrm{cc} / \mathrm{g}$ & $0.6640 \mathrm{cc} / \mathrm{g}$ \\
Average pore Radius & $18.1315 \AA$ & $12.8492 \AA$ \\
\hline
\end{tabular}




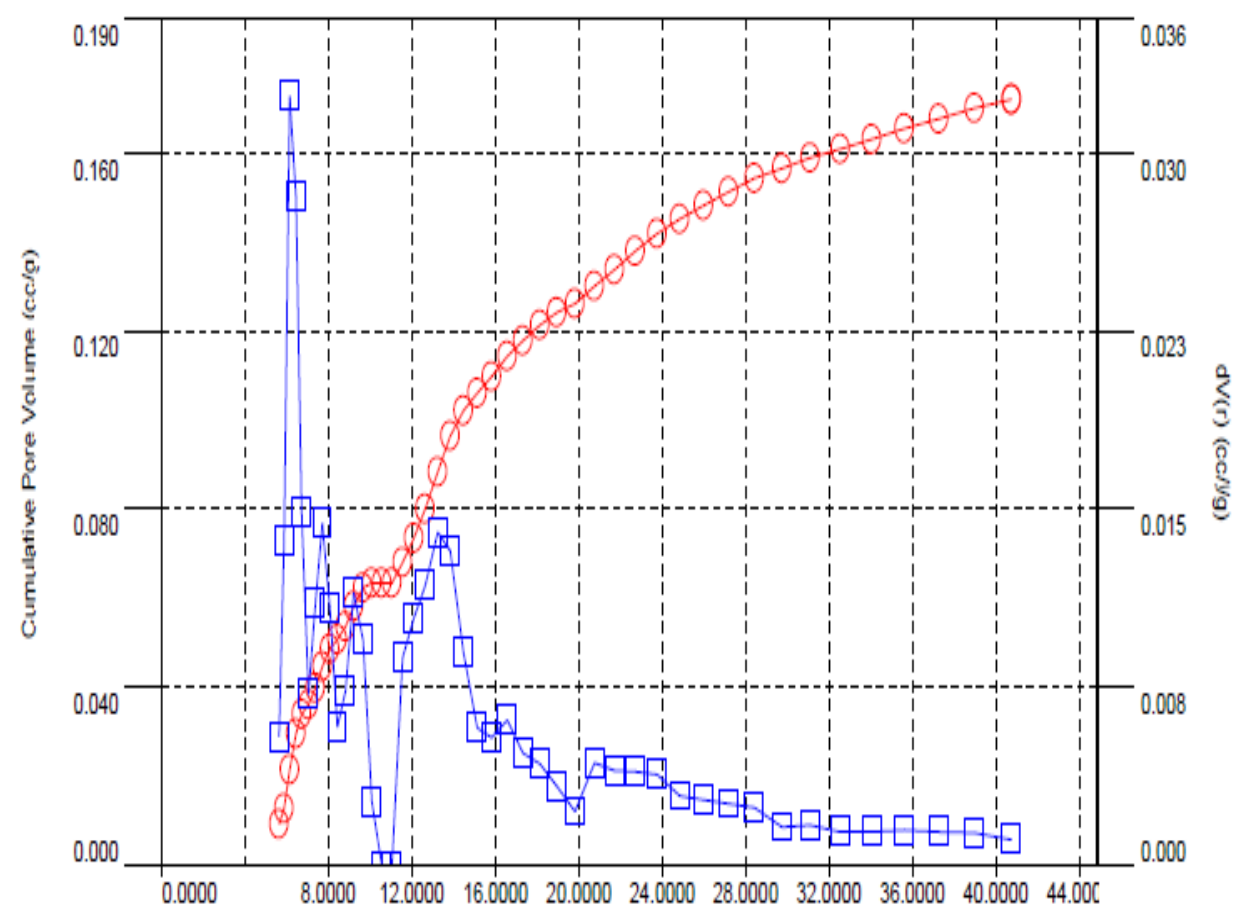

Fig (1) Half pore width (A) of RH activated carbon.

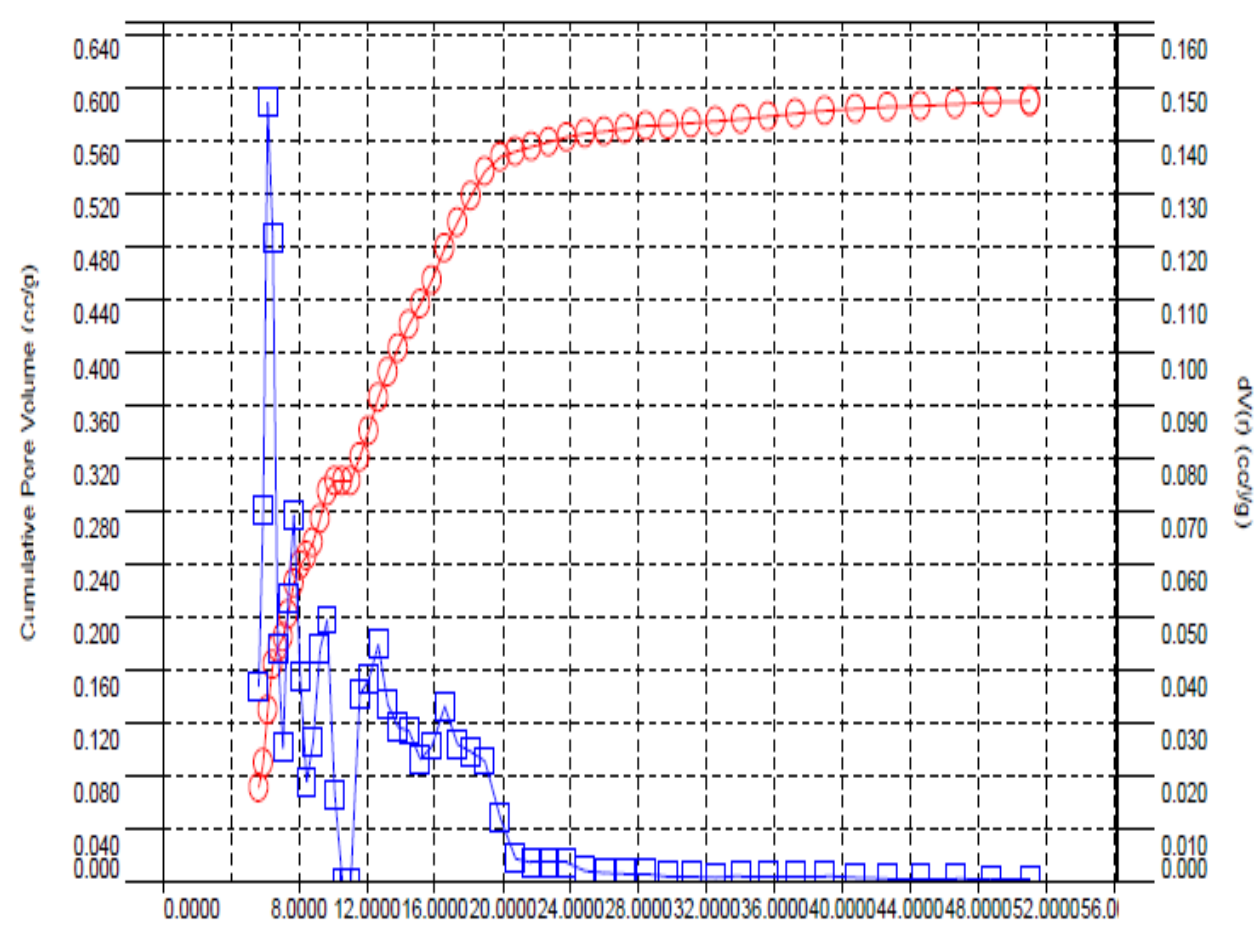

Fig (2) Half pore width (B) of SD activated carbon. 


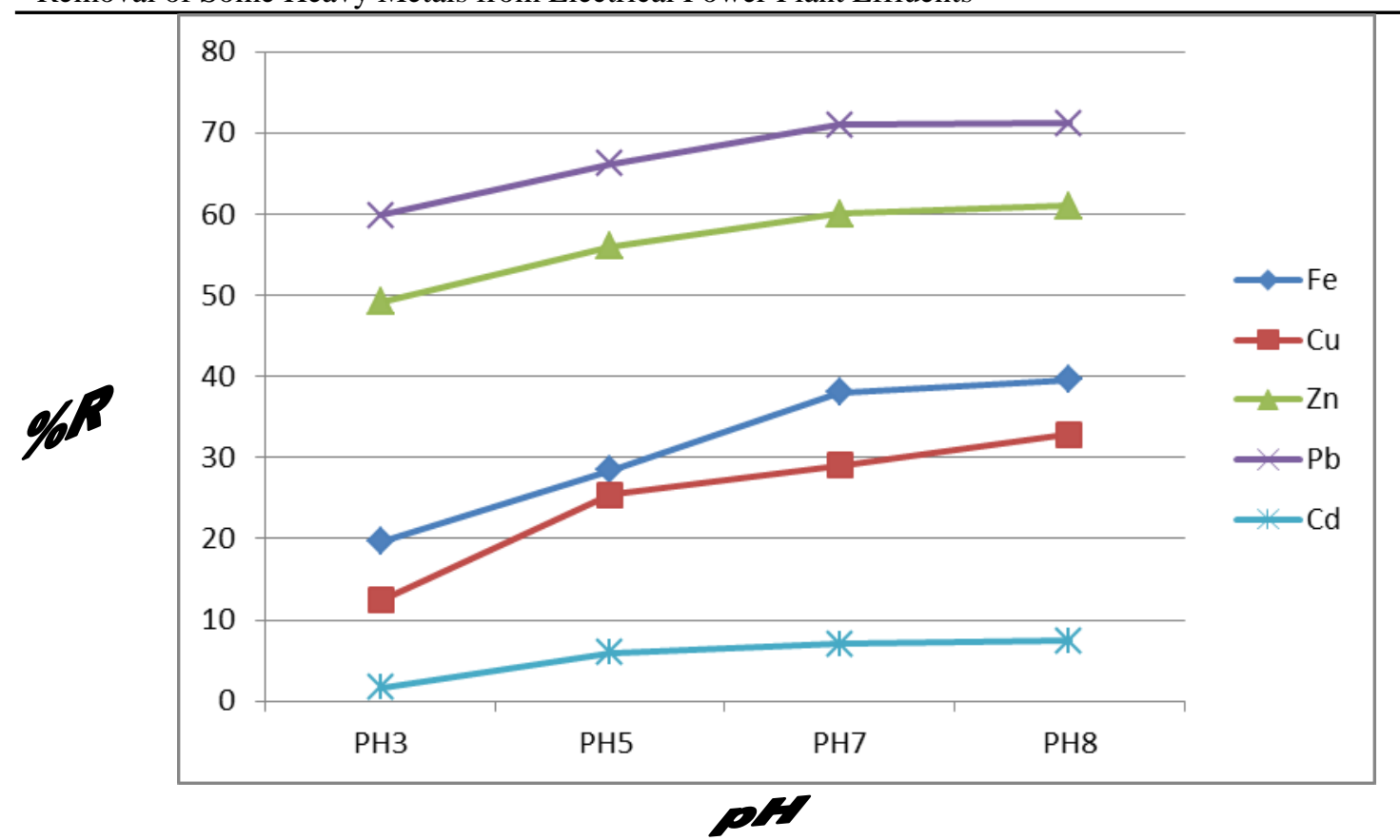

Fig (3) The effect of $\mathrm{pH}$ on the adsorption of heavy metals by activated carbon (A) at (contact time $=24 \mathrm{~h}$, agitation speed $=150 \mathrm{rpm}$, concent. $=50 \mathrm{mg} / \mathrm{l}$, mass of adsorbent $=0.05 \mathrm{~g}$, volume of solution $=10 \mathrm{ml}$ and temp. $=25{ }^{\circ} \mathrm{C}$.

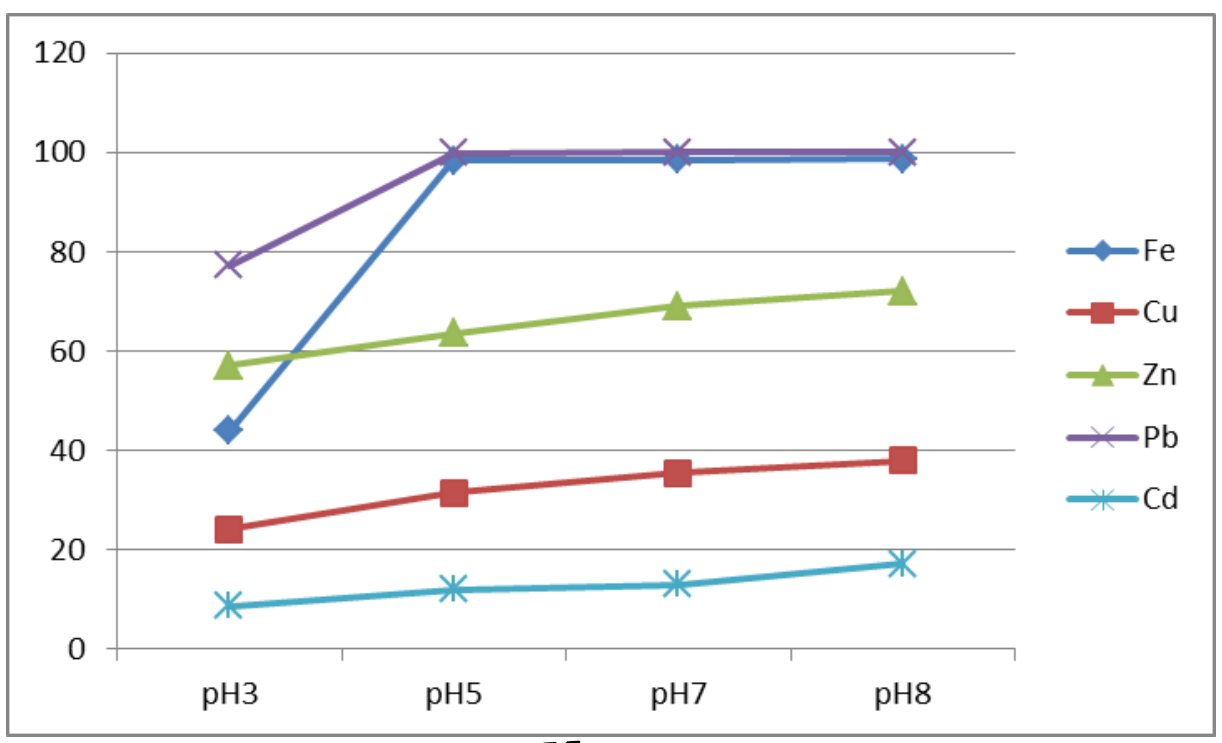

Fig (4) The effect of $\mathrm{pH}$ on the adsorption of heavy metals by activated carbon (B) at (time $=24 \mathrm{~h}$, agitation speed $=150 \mathrm{rpm}$, concent. $=50 \mathrm{mg} / \mathrm{l}$, mass of adsorbent $=0.05$ $\mathrm{g}$, volume of solution $=10 \mathrm{ml}$ and temp. $=25{ }^{\mathrm{O}} \mathrm{C}$.

\subsection{Sorption study}

Sorption isotherms could be described by different models such as Langmuir and Freundlich equations, depending on the metal species and the coexistence of other metal ions, at $\mathrm{pH} 7$ potentially190 $\mathrm{mg}$ of $\mathrm{Fe}^{2+}, 145$ of $\mathrm{Cu}^{2+}, 300 \mathrm{mg}$ of $\mathrm{Zn}^{2+}, 355 \mathrm{mg}$ of $\mathrm{Pb}^{2+}$, and $35 \mathrm{mg}$ of $\mathrm{Cd}^{2+}$ could be adsorbed per $\mathrm{Kg}$ of A.C. (A) whereas in case of using A.C. (B) it was found that $492 \mathrm{mg}$ of $\mathrm{Fe}^{2+}, 175$ of $\mathrm{Cu}^{2+}, 345 \mathrm{mg}$ of $\mathrm{Zn}^{2+}$, 499mg of $\mathrm{Pb}^{2+}$, and $65 \mathrm{mg}$ of $\mathrm{Cd}^{2+}$. The sorption equilibrium data were fitted by the non-competitive Langmuir model:

$$
\mathrm{q}_{\mathrm{e}}=\frac{\mathrm{q}_{\max } \mathrm{bC}_{\mathrm{e}}}{1+\mathrm{bC}_{\mathrm{e}}}
$$

Where $\mathrm{q}_{\mathrm{e}}$ is the amount of metal sorbed per unit mass of sorbent, $\mathrm{q}_{\max }$ is the maximum metal per unit mass of sorbent $(\mathrm{mg} / \mathrm{g})$.

$\mathrm{C}_{\mathrm{e}}$ is the equilibrium concentration of sorbate in solution $(\mathrm{mg} / \mathrm{g})$, and $\mathrm{b}$ is the Langmuir constant related to energy of sorption $(\mathrm{L} / \mathrm{mg}$ ) which reflects quantitively the affinity between the sorbent and the sorbate. From the experimental equilibrium data a nonlinear fit was performed by means of the program 
MATLAB in order to obtain the Langmuir model parameters this program minimizes the sum square of residuals (SSR)

$$
\mathrm{SSR}=\sum_{\mathrm{i}=1}^{\mathrm{N}} \mathbb{[}\left(\mathrm{q}_{\mathrm{i}}-\frac{\mathrm{q}_{\max } \mathrm{bc} \mathrm{c}_{\mathrm{i}} \rrbracket}{1+\mathrm{bc}}\right)^{2}
$$

The experimental data of $\mathrm{Fe}$ (II), $\mathrm{Cu}$ (II), Zn (II), $\mathrm{Pb}$ (II) and $\mathrm{Cd}$ (II) are plotted in Fig $(3,4)$ in these figures, it can be observed that experimental data have a good compliance with the calculated Langmuir isotherm curve, this fact indicates monolayer coverage on the A.C (a) and (b) surface by heavy metals investigated. Fitting of Langmuir isotherm equation to the data gathered from the equilibrium sorption experiments (symbols) initial $\mathrm{pH}: 7$, temperature $25+1{ }^{\circ} \mathrm{C}$. The $\mathrm{q}_{\max }$ obtained in this study for $\mathrm{Fe}$ (II), $\mathrm{Cu}$ (II), Zn (II), Pb (II) and Cd (II) onto A.C. (a) and (b) was compared to the reported in the literature [1-8] for some A.C. and it was found that A.C. (a) and (b) were more effective upon the removal of these toxic heavy metal from water resources.

\subsection{Adsorbent dose}

The effect of sorbent dose as one of parameters that strongly affects the adsorption capacity is shown in Fig (5) It can be observed that with the mixed $\mathrm{Pb}$
(II), $\mathrm{Zn}$ (II), $\mathrm{Fe}$ (II), $\mathrm{Cd}$ (II) and $\mathrm{Cu}$ (II) concentrations, the amount of removed $\mathrm{Pb}$ (II), $\mathrm{Zn}$ (II), $\mathrm{Fe}$ (II), $\mathrm{Cd}$ (II) and $\mathrm{Cu}$ (II) ions increases with the increase of the adsorbent weight. After a certain adsorbent dosage the removal efficiency is not increased significantly. The maximum removal efficiency was achieved at an adsorbent dosage level $0.1 \mathrm{~g} / \mathrm{l}$.

\subsection{Effect of temperature}

To study the effect of temperature on adsorption of $\mathrm{Pb}$ (II), $\mathrm{Zn}$ (II), $\mathrm{Fe}$ (II), $\mathrm{Cd}$ (II) and $\mathrm{Cu}$ (II), different experiments were carried out in the range $25-60^{\circ} \mathrm{Cwith}$ a contact time for $24 \mathrm{~h}$. It can be observed from Fig (6) The adsorption percent was increased with increasing the temperature.

\subsection{Desorption experiments}

Desorption experiments put into evidence that after 24 hours contact $\mathrm{HCl}$ solutions were more efficient than $\mathrm{NaOH}$ solutions to desorbs $\mathrm{Fe}$ (II), $\mathrm{Cu}$ (II), $\mathrm{Zn}$ (II), $\mathrm{Pb}$ (II) and $\mathrm{Cd}$ (II) for the (a) and (b) presented in Fig $(7,8)$ As seen, the maximum Fe (II), $\mathrm{Cu}$ (II), $\mathrm{Zn}$ (II), $\mathrm{Pb}$ (II) and $\mathrm{Cd}$ (II) desorption percentage $(98.6 \%)$ was obtained for the highest $\mathrm{HCl}$ concentration $(1.5 \mathrm{~mol} / \mathrm{L})$ used.

Table (2) Amount of element adsorbed on adsorbent of heavy metals ions $\left(\mathrm{F}_{\mathrm{e}}, \mathrm{Cu}, \mathrm{Zn}, \mathrm{Pb}\right.$ and $\left.\mathrm{Cd}\right)$ of the concentration with variation of $\mathrm{pH}$ at temp. of $25^{\circ} \mathrm{C}$ for activated carbon (a).

\begin{tabular}{lccccccccccc}
\hline $\mathbf{p H}$ & $\begin{array}{c}\mathbf{F e} \\
\mathbf{m g} / \mathbf{l}\end{array}$ & $\begin{array}{c}\mathbf{q} \mathbf{m} / \mathbf{g} \\
\mathbf{m g}\end{array}$ & $\begin{array}{c}\mathbf{C u} \\
\mathbf{m g} / \mathbf{l}\end{array}$ & $\begin{array}{c}\mathbf{q} \mathbf{m g} / \mathbf{g} \\
\mathbf{m}\end{array}$ & $\begin{array}{c}\mathbf{Z n} \\
\mathbf{m g} / \mathbf{l}\end{array}$ & $\begin{array}{c}\mathbf{q}_{\mathbf{e}} \\
\mathbf{m g} / \mathbf{g}\end{array}$ & $\begin{array}{c}\mathbf{P b} \\
\mathbf{m g} / \mathbf{l}\end{array}$ & $\begin{array}{c}\mathbf{q e} \\
\mathbf{m g} / \mathbf{g}\end{array}$ & $\begin{array}{c}\mathbf{C d} \\
\mathbf{m g} / \mathbf{l}\end{array}$ & $\begin{array}{c}\mathbf{q e} \\
\mathbf{m g} / \mathbf{g}\end{array}$ \\
\hline 3 & 40.20 & 0.98 & 43.80 & 0.62 & 25.40 & 2.46 & 20.10 & 2.99 & 48.20 & 0.18 \\
5 & 35.80 & 1.42 & 37.30 & 1.27 & 22.00 & 2.80 & 16.90 & 3.31 & 47.00 & 0.30 \\
7 & 31.00 & 1.90 & 35.50 & 1.45 & 20.00 & 3.00 & 14.50 & 3.55 & 46.50 & 0.35 \\
8 & 30.20 & 1.98 & 33.60 & 1.64 & 19.50 & 3.05 & 14.40 & 3.66 & 46.30 & 0.37 \\
\hline
\end{tabular}

Table (3) Amount of element adsorbed on adsorbent of heavy metal ions $\left(\mathrm{F}_{\mathrm{e}}, \mathrm{Cu}, \mathrm{Zn}, \mathrm{Pb}\right.$ and $\left.\mathrm{Cd}\right)$ of the concentration with variation of $\mathrm{pH}$ at temp. $25^{\circ} \mathrm{C}$ which corresponding to activated carbon (b).

\begin{tabular}{|c|c|c|c|c|c|c|c|c|c|c|}
\hline pH & $\begin{array}{c}\mathrm{F}_{\mathrm{e}} \\
\mathrm{mg} / \mathrm{l}\end{array}$ & $\begin{array}{c}q_{\mathrm{e}} \\
\mathrm{mg} / \mathrm{g}\end{array}$ & $\begin{array}{c}\mathrm{Cu} \\
\mathrm{mg} / \mathrm{l}\end{array}$ & $\begin{array}{c}\mathrm{q}_{\mathrm{e}} \\
\mathrm{mg} / \mathrm{g}\end{array}$ & $\begin{array}{c}\mathrm{Zn} \\
\mathrm{mg} / \mathrm{l}\end{array}$ & $\begin{array}{c}q_{\mathrm{e}} \\
\mathrm{mg} / \mathrm{g}\end{array}$ & $\begin{array}{c}\mathrm{Pb} \\
\mathrm{mg} / \mathrm{l}\end{array}$ & $\begin{array}{c}\mathrm{q}_{\mathrm{e}} \\
\mathrm{mg} / \mathrm{g}\end{array}$ & $\begin{array}{c}\mathrm{Cd} \\
\mathrm{mg} / \mathrm{l}\end{array}$ & $\begin{array}{c}\mathrm{qe} \\
\mathrm{mg} / \mathrm{g}\end{array}$ \\
\hline 3 & 28.00 & 2.20 & 37.90 & 1.2 & 21.50 & 2.85 & 1.40 & 3.86 & 45.70 & 0.43 \\
\hline 5 & $<0.87$ & 4.91 & 34.30 & 1.57 & 18.20 & 3.18 & $<0.12$ & 4.98 & 44.00 & 0.60 \\
\hline 7 & 0.75 & 4.92 & 32.50 & 1.75 & 15.50 & 3.45 & 0.02 & 4.99 & 43.50 & 0.65 \\
\hline 8 & 0.69 & 4.93 & 30.80 & 1.92 & 14.00 & 3.60 & 0.02 & 4.99 & 41.40 & 0.86 \\
\hline
\end{tabular}

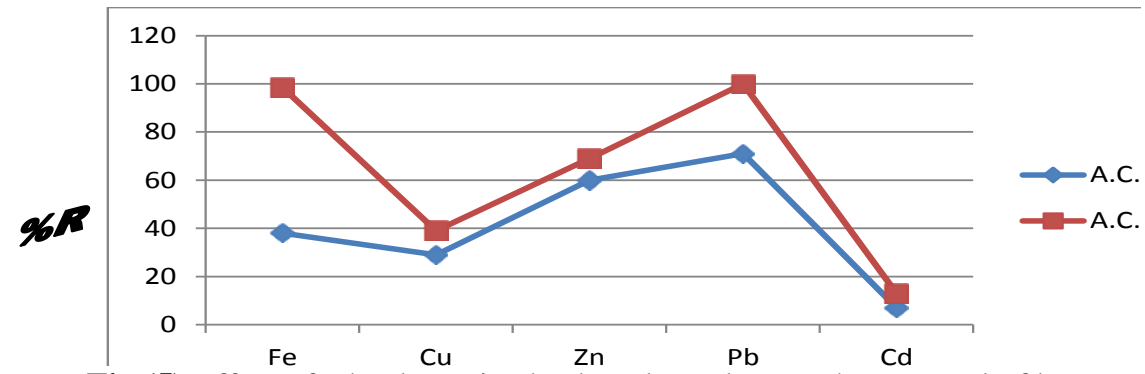

Fig (5) Effect of adsorbent rice husk and sawdust on the removal of heavy metals with concentration of $50 \mathrm{mg} / \mathrm{l}, \mathrm{pH}=7$, temp. $25^{\circ} \mathrm{C}$, time $=24 \mathrm{~h}$ and $0.1 \mathrm{~g}$ of adsorbent with $10 \mathrm{ml}$ from solution 


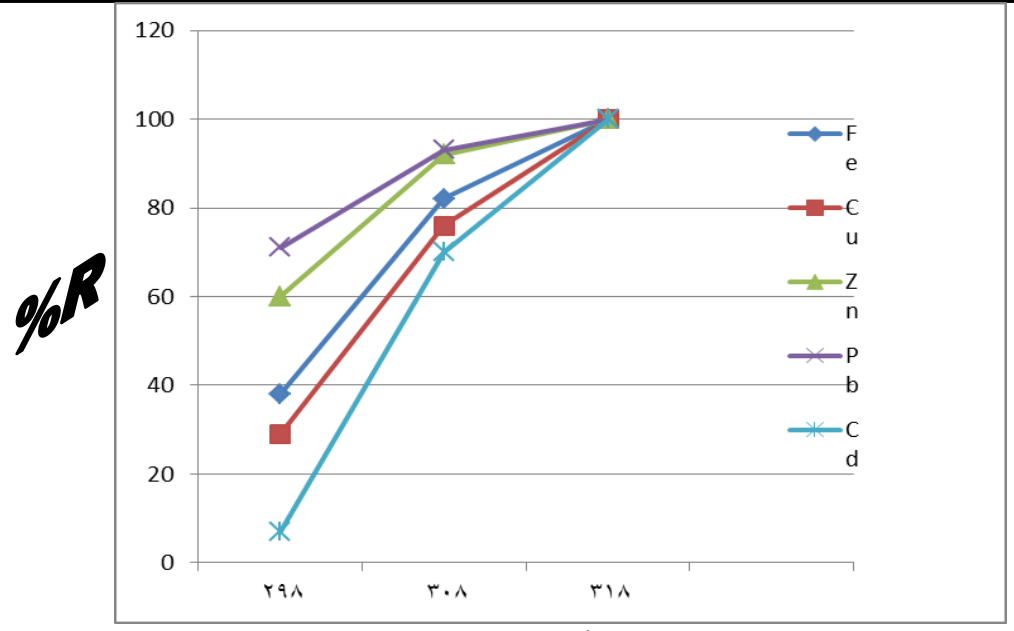

\section{Temperature}

Fig (6) Effect of temperature on the adsorption of different metals by activated carbon (a) at concentration of 50 $\mathrm{mg} / \mathrm{l}$, adsorbent dose $0.05 \mathrm{~g}$ and $\mathrm{pH}=7$.

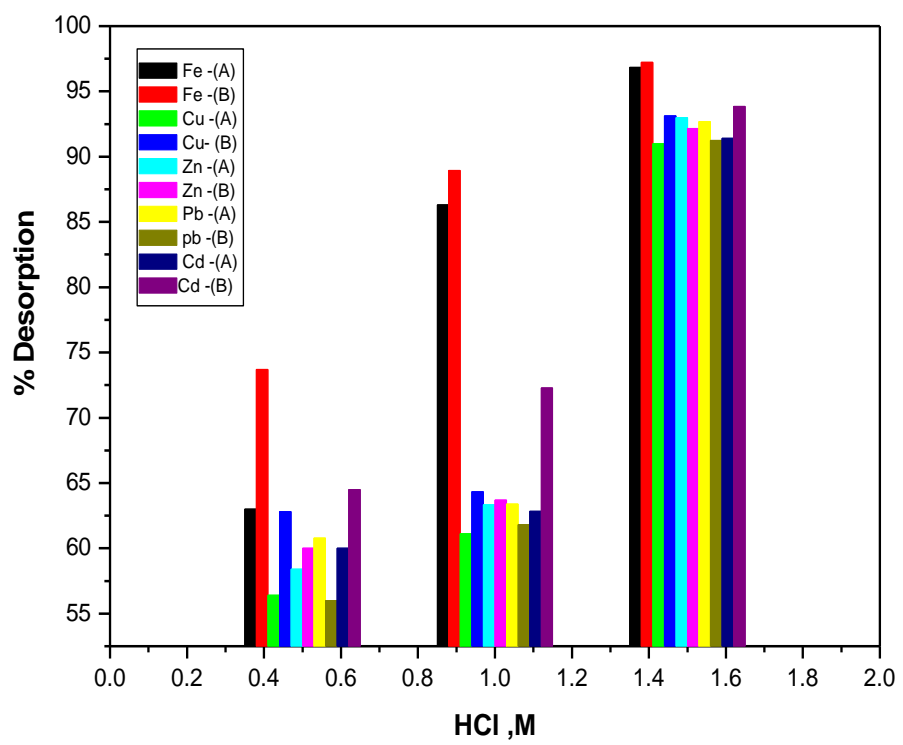

Fig (7) Desorption rate of heavy metals from Activated carbon (a) and (b) by different concentration of $\mathrm{HCl}$

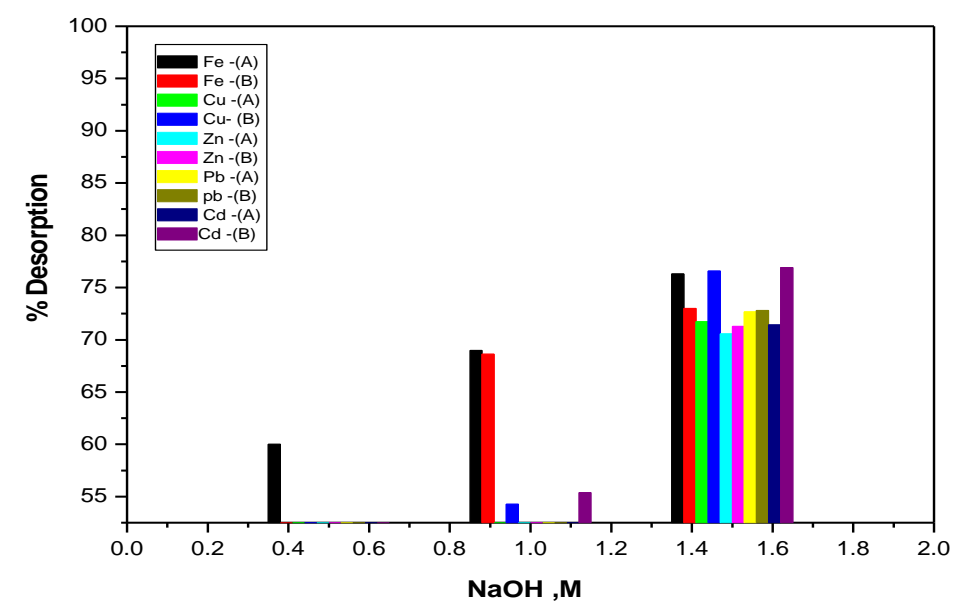

Fig (8) Desorption rate of heavy metals from Activated carbon (a) and (b) by different concentration of $\mathrm{NaOH}$. 


\section{Conclusion}

1- Utilization of material to manufacture activated carbon for treating $\mathrm{Fe}$ (II), $\mathrm{Cu}$ (II), $\mathrm{Zn}$ (II), $\mathrm{Pb}$ (II) and Cd (II) contaminated River Neil water is value added strategy.

2- Batch adsorption experiments were conducted to investigate capacity of A.C. (a) and (b) possessed significantly higher adsorption capacity for $\mathrm{Fe}$ (II), $\mathrm{Cu}$ (II), $\mathrm{Zn}$ (II), $\mathrm{Pb}$ (II) and $\mathrm{Cd}$ (II).

3- $\mathrm{HCl}$ solutions were more efficient than $\mathrm{NaOH}$ solutions to desorbs $\mathrm{Fe}$ (II), $\mathrm{Cu}$ (II), $\mathrm{Zn}$ (II), $\mathrm{Pb}$ (II) and Cd (II) from A.C. (a) and (b).

4- The study suggests that ecumenically manufacturing granular activated carbon that is to be used in contaminated River Neil water for removing of heavy metals.

\section{References}

[1] X.Wang, Y.Guo, L.Yang, M.Han, J.Zhao and X.Cheng, Nan materials as Sorbents to Remove Heavy Metal Ions in Wastewater Treatment. J.Environ. and Anal.Toxicology, vol.27, pp.1 -7, 2012.

[2] C.Quintelas, Z.Rocha, B.Silva, B.Fonseca, H.Figueiredo, T.Tavares, Removal of Cd (II), $\mathrm{Cr}(\mathrm{VI}), \quad \mathrm{Fe}(\mathrm{III})$ and $\mathrm{Ni}(\mathrm{II})$ from aqueous solutions by an E. coli biofilm supported on kaolin. Chem. Eng. J. vol.149, 319-324, 2009.

[3] A.E.Pagana, S.D.Sklari, E.S.Kikkinides, V.T.Zaspalis, Microporous ceramic membrane technology for the removal of arsenic and chromium ions from contaminated water. MicroporousMesoporous Mater, vol.110(1), pp.150-156, 2008.

[4] D.Bǒzic, V.Stankovi'c, M.Gorgievskia, G.Bogdanovic and R.Kovacevic, Adsorption of heavy metal ions by sawdust of deciduous trees. J. Hazard. Mater. Vol.171, pp.684-692, 2009.

[5] X.Qu, P.J.J.Alvarez and Q.Li, Applications of nanotechnology in water and wastewater treatment. Water Res, vol.47 , pp.3931 -3946, 2013.

[6] J.M.D.Simone, Practical Approaches to Green Solvents. Science. Vol.297(5582), pp.799-803, 2002.

[7] P.Raveendran, J.Fu, S.L.Wallen, Completely green synthesis and stabilization of metal nanoparticles. J.Am.Chem. Soc. Vol.125, pp. 13940-13941, 2003.

[8] K.G.Sreejalekshmi, K.A.Krishnan and T. S.Anirudhan, Adsorption of $\mathrm{Pb}(\mathrm{II})$ and $\mathrm{Pb}(\mathrm{II})$ citric acid on sawdust activated carbon: Kinetic and equilibrium isotherm studies. J. Hazard. Mater, vol.161, pp.1506-1513, 2009.

[9] H.M.H.Gad, F.Yasser, F.Lasheen \& Ayman , Seliman, "Sorption of Technetium-99 from lowlevel radioactive waste using different adsorbent materials. Accepted for publication in Asian Jpurnal of Chemistry, vol.27(11), 2015. 